Article

\title{
Becoming Monolingual: The Impact of Language Ideologies on the Loss of Multilingualism on São Tomé Island
}

\author{
Marie-Eve Bouchard $(D)$ \\ Department of Romance Studies and Classics, Stockholm University, 10691 Stockholm, Sweden; \\ marie-eve.bouchard@su.se
}

Received: 13 May 2019; Accepted: 28 June 2019; Published: 30 June 2019

\begin{abstract}
This article discusses the loss of the creole languages on São Tomé Island and the societal move from multilingualism to monolingualism in Portuguese. It argues that recognizing the ideologies attached to these languages is key in understanding the language shift, but also the processes leading toward monolingualism. This qualitative study is based on three main theories: Language as social practice, language ideology, and monoglot standardization. Data comes from ethnographic fieldwork and sociolinguistic interviews with 56 speakers from the capital of São Tomé and Príncipe. I argue that the existence of multilingualism on São Tomé Island is not valued at a societal level because of the pejorative ideologies that have been held about the creole languages since colonial times. Also, the use of the creole languages stood as a problem for the creation of a unified Santomean nation, as the different racial groups on the islands had their own creole. Results show how ideologies about the Portuguese language and its association with national unity, modernity, and European-ness favored its expansion on São Tomé Island and a move toward monolingualism.
\end{abstract}

Keywords: language ideology; monolingualism; Portuguese language; language shift; São Tomé and Príncipe

\section{Introduction}

This article focuses on the growing loss of societal multilingualism on São Tomé Island as a consequence of ideologies held regarding the use of Portuguese and creole languages. From the seventeenth century to the middle of the nineteenth century, Portuguese in São Tomé and Príncipe was in a diglossic relation (Ferguson 1959) with three creole languages indigenous to the islands (Forro, Angolar, Lung'ie) - a situation that favored the maintenance of the creoles on the islands. As it was common in colonial contexts, the language of the colonizers, Portuguese in this case, was the high variety, spoken by the administration, and probably a restricted number of Portuguese nationals and a few Africans who were in close contact with them. ${ }^{1}$ The local Portuguese-based creoles were the low varieties, spoken in the everyday life of the former slaves who were the majority in number on the islands. However, with the massive arrival of indentured laborers (coming mainly from Angola, Cape Verde, and Mozambique (Seibert 2006)) starting at the end of the nineteenth century, the sociolinguistic picture of the islands was transformed. Portuguese became the lingua franca (i.e., the means to bridge a language gap (Edwards 2013)) between the different linguistic groups. Later on, with the independence

1 Most of the Portuguese colonists lost interest in São Tomé Island during the seventeenth and eighteenth centuries. The Forros then climbed in the social scale of the island, and their creole language probably did so as well, cf. (Lorenzino 1998). So even if Portuguese was the language of the administration, the prestige language might have been Forro during this period (Bouchard forthcoming a). 
of the country in 1975 and the choice of Portuguese as the only official language of São Tomé and Príncipe, Portuguese also became a symbol of national unity. As a consequence, the process of language shift that has been taking place in São Tomé and Príncipe since the beginning of the twentieth century was intensified, and since then, Santomeans are becoming monolingual in Portuguese.

This article offers a social perspective on the processes of becoming collectively monolingual. It situates the study of the growing loss of multilingualism on São Tomé Island in the domains of ideology and social practices (cf. Heller 2007). This allows us to examine the reasons behind the loss of multilingualism on São Tomé Island, and the ways in which the Santomean society is moving toward monolingualism. ${ }^{2}$

This study can also be situated within a broader reality: the rapid loss of linguistic diversity in Africa, which is also resulting in the loss of human knowledge. According to Batibo $(2005$, p. 155) and data from Ethnologue, only $15.8 \%$ of African languages are safe; the other $74.2 \%$ are endangered or extinct. The native creole languages of São Tomé and Príncipe do fit in this picture: Lung'ie is basically extinct, Forro is in danger, and although Angolar is relatively safe for now, things will most probably change as all Santomeans are becoming more and more monolingual. According to Batibo (2009, p. 90), language loss in Africa in related to historical legacies, socioeconomic inequalities, demographic imbalances, and sociopolitical pressures. In most cases, people first shift from minority languages to a progressive use of dominant languages marked by bilingualism, and then abandon the minority languages in favor of the dominant languages. These dominant languages are usually the ones that play important public roles and are used in education, administration, wider communication, etc. The pressure exerted on minority languages is greater when a dominant language has been promoted to assume a national and unifying role, such as Portuguese in São Tomé and Príncipe.

In this article, I argue that the existence of multilingualism on São Tomé Island is not valued at a societal level because of the pejorative ideologies that have been held about the creole languages since colonial times. Also, the use of the creole languages stood as a problem for the creation of a unified Santomean nation, as the different racial groups on the islands had their own creole. These obstacles to the maintenance of creoles were combined with another strong ideology: One language, one nation. In fact, nations are often perceived as linguistic and culturally homogenous entities (cf. Hobsbawm 1990). So Portuguese was the language used in the creation of the Santomean nation, and multilingualism was not integrated in the Santomean nation-building project at the time of its independence in 1975.

São Tomé and Príncipe was once characterized by its great linguistic diversity, and has been called a "labyrinth and laboratory of languages" (translated from Hagemeijer forthcoming). However, even so, little to no studies on the languages of these islands from a multilingual or bilingual approach exist. ${ }^{3}$ Linguists who have taken interest in the Santomean languages have mainly focused on describing the creole languages (e.g., Ferraz 1974; Maurer 1992, 1995; Lorenzino 1996, 1997; Hagemeijer 2009a), investigating the interaction between Portuguese and the creoles (e.g., Afonso 2008, 2009; D'Apresentação 2013), and studying the emergent variety of Santomean Portuguese (e.g., Brandão 2011; Gonçalves 2010, 2016; Bouchard 2017, 2018, 2019, forthcoming b). This paper fills in the gap by delving into the processes that lead the Santomean society to choosing monolingualism over multilingualism.

The article is divided as follows. Section 2 offers a sociohistorical and linguistic overview of São Tomé and Príncipe, in order to better situate this study in its context. Section 3 introduces the theoretical framework and briefly reviews the literature on language as a social practice, language

2 Note that I am not concerned with individual bilingualism (or what Hamers and Blanc (2000) call bilinguality), but rather with societal bilingualism and multilingualism, although both are closely connected (cf. Butler 2013). Also, I use the terms bilingualism and multilingualism interchangeably; they both contrast with monolingualism and refer to the use of two or more languages in a society. I acknowledge that it is important to make a distinction between bilingual and multilingual individuals, but in this case, I only want to draw a line between multilanguage users or societies and non-multilanguage users or societies.

3 The only exception I know of is Afonso's (2008) master's thesis, in which she advocates for the teaching of Portuguese as a second language (L2) in the Santomean school system. 
ideology, and monoglot standardization. Section 4 presents the methodology, and Section 5 displays and discusses different interview excerpts that support my argument in showing how and why the Santomean society is becoming more and more monolingual. Section 6 concludes this article.

\section{A Brief Sociohistorical and Linguistic Overview of São Tomé Island}

In this section, I offer a very brief overview of the history of São Tomé and Príncipe, focusing on its languages. For a thorough review of the history of the islands, refer to Eyzaguirre (1986), Hodges and Newitt (1988), Garfield (1992), Henriques (2000), and Seibert (2006), among others.

The archipelago of the Gulf of Guinea, in the Atlantic Ocean, was taken into Portuguese colonial control in the 1470s. The archipelago is constituted of four islands: São Tomé and Príncipe that form the country of the same name, and Annobón and Bioko, which are part of Equatorial Guinea. The exact dates of the discoveries of the islands are uncertain; historians waver between 1470, 1471, and 1472. Most agree that all were inhabited, except for Bioko, which was inhabited by the African population Bubi (Bantu people) (cf. Yakpo 2009). The first Portuguese colony was established on São Tomé Island in 1485 with great difficulty, mainly because of the remoteness of the island, its humid climate, and its tropical diseases (Disney 2009). However, the islands of the Gulf of Guinea quickly became economically important for Portugal; they played an essential role in sugar cane cultivation and slave traffic. At the end of the fifteenth century, with the settlement of the Portuguese and their African slaves on São Tomé Island, it is likely that a new linguistic system had started to develop. That system, called "proto-Gulf of Guinea Creole" (henceforth, pro-GGC), would be at the root of the four creoles of the Gulf of Guinea: Forro, Angolar, Lung'ie, and Fa d'Ambô (e.g., Ferraz 1979; Hagemeijer 1999; Schang 2000; Bandeira 2017). According to Hagemeijer (2000), the proto-GGC evolved into what is today Forro. Angolar is a descendant of this proto-GGC, but also the outcome of a society of runaway enslaved Africans (Lorenzino 1998), while Lung'ie and Fa d'Ambô are historical results of varieties of the proto-GGC whose speakers settled on Príncipe Island and Annobón Island, respectively (Hagemeijer 2009b). Ferraz (1979) was the first to link the four creoles; before him, Angolar was thought to be an unrelated creole. The differences between these four languages can be explained by their early separation from one another.

The prosperity of the plantation economy on São Tomé Island only lasted about seventy years (during the 16th century). Because of the humidity, the quality of the sugar was inferior to the sugar made by the Portuguese in Madeira and Brazil. São Tomé Island had also become unstable and unsafe because of the attacks by runaway enslaved Africans. In addition to this, the Portuguese authorities were disorganized and corrupt, there were permanent disagreements between the church and civil authorities on the island and conflicts between the colony and the metropolis, and a disease destroyed much of the sugar cane crop (Henriques 2000). These factors contributed to the emigration of many planters to Brazil, where opportunities were more promising. The Portuguese authorities had lost control over the island, and the number of white settlers drastically diminished. According to Seibert (2006, p. 30), because of this decrease in number of white settlers on São Tomé Island, the remaining inhabitants, whom he calls the creoles, "became steadily more African by blood".

The year of 1852 was marked by the beginning of the second colonization of São Tomé e Príncipe by Portugal. World prices and demand for tropical products such as palm oil, coffee, and cocoa were rising (Hodges and Newitt 1988). São Tomé and Príncipe took advantage of this reorientation of economic activity. Coffee plants had been introduced in Príncipe in 1787, and cacao trees in 1822 (Seibert 2006). But the lack of workforce was problematic. Trafficking of slaves was officially abolished in the Portuguese territories in 1836 and slavery itself in $1858^{4}$, although the slave trade to Brazil

4 Even so, slavery continued illegally. In São Tomé and Príncipe, the former slaves became libertos 'freedman', but they had to continue to work for their masters. Clandestine trafficking continued, and from 1864, slaves were imported from Gabon (Hodges and Newitt 1988). 
persisted until 1851, where slavery was not abolished until 1888. According to Hodges and Newitt (1988, p. 28), "there were chronic labor shortages, as the free inhabitants of the islands (known as forros or filhos da terra) were unwilling to undertake plantation work." The same was true of the Angolares who have always refused to work on plantations, preferring to remain fishermen. But the demand for a work force was high, so the Portuguese decided to bring in labor from abroad. In 1875, they created the Curadoria Geral dos Indigenas, a labour bureau to recruit workers on the African mainland. Those workers were called serviçais 'servants' or contratados 'contract laborers'. According to Hodges and Newitt (1988, pp. 36-37), "an average of 4000 laborers a year had to be imported to maintain a work force of between 30,000 and 40,000." The contratados signed a contract before going to the islands; they were committing to five years of work, after which they could renew their contract or be repatriated. Between 1876 and 1879, these workers were mainly coming from Angola, Gabon, Gold Coast and Liberia; after 1879, they were exclusively recruited in Angola, Cape Verde, and Mozambique (Seibert 2006). Slavery had been abolished, but this was in effect a continuation of it in several respects (Bouchard 2017).

With those contracted laborers, São Tomé and Príncipe witnessed a population boom. With a population of around 12,000 in 1850, it climbed to 64,221 around 1900 (Lorenzino 1998). Such a demographic event had an impact at the linguistic level, as these non-native speakers of Portuguese came with their respective languages. Among those languages, the main ones were Cape Verdean Creole, and Kimbundu and Umbundu (from Angola) (Hagemeijer 2009b). On the one hand, Cape Verdeans were numerous and often arrived with their family, which facilitated the use and the preservation of their native language, called kriolu. As a consequence, Cape Verdean Creole is still spoken on both islands, especially in Príncipe, where about $25 \%$ of the population speaks it (INE 2012a) $)^{5}$. On the other hand, as Hagemeijer (2009c, p. 17) wrote, "the predominance of the speakers of Kimbundu and Umbundu in certain plantations led to the appearance of a contact language called the Portuguese of the Tonga". The Tongas are the descendants of the contratados; they are children who grew up in plantations and who learned the Portuguese L2 (second language) spoken by the people in their surroundings. More specifically, Baxter (2002, p. 11) wrote that the descendants of the contratados "acquired Portuguese on the basis of Primary Linguistic Data [ ... ] which must have been heavily influenced by adult-acquired L2 Portuguese (and by Tonga L1 [first language] Portuguese, itself heavily influenced by workforce L2 Portuguese)." The Portuguese of the Tonga is a variety influenced by the native languages of the contratados and Santomean Portuguese.

São Tomé and Príncipe became independent in 1975. The independence of the country is remembered by older Santomeans as a peaceful transition. With the president Manuel Pinto da Costa, São Tomé and Príncipe was independent, but not democratic. Pinto da Costa had established a one-party regime with a Marxist party in power that lasted until 1990. During that year, inspired by the Portuguese system, a multiparty and semi-presidential system in which the Prime Minister is the head of the government was installed. Since then, São Tomé and Príncipe has had regularly peaceful (but not without any problems) alternation of governments.

Nowadays, São Tomé and Príncipe is the only African country where most of the population speaks Portuguese as a first language. ${ }^{6}$ Portuguese is spoken by $98.4 \%$ of the population (as a L1 or L2). Among the autochthonous languages, Forro is still today the most widely spoken creole in the country, with $36.2 \%$ of the population reporting speaking it. Also, $6.6 \%$ or the population reported speaking Angolar, and 1.0\% reported speaking Lung'ie. Note that $8.5 \%$ of the population also reported speaking Cape Verdean Creole (INE 2012a).

5 Unfortunately, no studies on the variety of Cape Verdean Creole spoken in São Tomé Island and Príncipe have yet been done. 6 Processes of nativization of Portuguese are also underway in Angola and Mozambique (Hagemeijer 2018). 


\section{Monolingualism as a Social, Political, and Ideological Practice}

This paper is based on three main theories: Language as social practice, language ideology, and monoglot standardization.

First, it situates the study of language use within a socio-contextual view, following Heller (2007, p. 2) who wrote that "understanding language as a set of ideologically-defined resources and practices constructs language as a fundamentally social phenomenon." This means that language is studied in relation to the society-both cannot be separated. Seeing language as a social practice refers to what speakers do in, with, and through language, rather than focusing on their linguistic knowledge. In this view, the hierarchy of languages in a given society is not linguistic but rather social and political: "language is but one terrain for the construction of relations of social difference and social inequality" (Heller 2007, p. 2). In this article, I view monolingualism, bilingualism, and multilingualism as a social construct, but also as a political construct. Multilingualism was not integrated in the Santomean nation-building project. It is actually not part of public discourse as it is in Quebec, Catalunya and Corsica, for example, which are territories where minority languages are in contact with a dominant language.

Second, language ideology is a conceptual tool used to access what speakers think, feel, and believe with regard to different languages and linguistic features (Woolard 1998). Language ideology is a way of thinking loaded with political, social, and economic interest (Irvine 1989). Since colonial times, Portuguese has been constructed as a pointer of the powerful, educated, and elegant people, while the creole languages were rather associated with inferiority, primitiveness, and being "more African" (Bouchard 2017). ${ }^{7}$ I believe that accessing ideologies is key to understanding why and how Santomeans are collectively becoming monolingual, as the existence of multilingualism is the nation-state of São Tomé and Príncipe is not being valued—but speaking Portuguese is. In her paper about bilingualism in Corsica, Jaffe (2007) asks the following question: "how is 'bilingualism' as an ideological construct experienced and defined within the ideological framework of 'shift'?" This question is very appropriate to the Santomean context, where a language shift is underway (and is more advanced in some parts of the country, such as São Tomé City, the capital) since the beginning of the twentieth century. I will try to answer this question, while focusing on the ideological meaning of monolingualism. This brings me to the third theory, the monoglot standard.

Silverstein (1996, p. 284) refers to the desire of a nation-state to be an officially unified society under one language, which he calls "The Standard". Referring to the United Stated, Silverstein (1996, p. 284) wrote that "we live in a society with a culture of monoglot standardization underlying the constitution of our linguistic community and affecting the structure of our various and overlapping speech communities." This applies to the Santomean context, where Portuguese is constructed and viewed as The Standard, the "best" language, and where the creole languages do not quite seem to be "real" languages (Bouchard 2017). In fact, they were for many years perceived as a dialect of Portuguese, and not as a language per se. The name dialeto 'dialect' has remained to refer to Forro, the most widely spoken creole on São Tomé Island (Bouchard 2017). Portuguese in São Tomé and Príncipe is an instrument, it has a functional utility: at a societal level, it is central to the formation of a unified national, and at an individual level, it gives access to the work market and better opportunities, to a higher social status, and to social recognition, among other things. But there is also a hierarchy among the different varieties of Portuguese. For example, urban Santomean Portuguese is more positively perceived than rural Santomean Portuguese (Bouchard forthcoming b), and European Portuguese is still viewed as more prestigious than any varieties of Santomean Portuguese (Bouchard 2017). In fact, I believe this last statement to be the case in all former Portuguese colonies of Africa. The Portuguese language is endowed with claims and beliefs of superiority to the creole and native languages of Africa.

7 To know more about the concept of language ideology and how I apply it to the Santomean reality, refer to Bouchard (2017, 2018, forthcoming a, forthcoming $b$ ). 
Therefore, not speaking Portuguese, or not speaking a good Portuguese, is perceived as a deficit. The culture of monoglot standardization in São Tomé and Príncipe can be observed through people's understanding of languages (i.e., languages ideologies), their language use, public and everyday discourse, etc.

\section{Methods, Participants, and Data}

This research is based on fifteen months of ethnographic fieldwork and sociolinguistic interviews on São Tomé Island (between June 2015 and March 2017). I have continued to live on São Tomé Island after I completed my fieldwork research, for a total stay of about two years. I recorded 118 participants from different communities of the islands of São Tomé and Príncipe, but this study is based on tape-recorded sociolinguistic interviews (Labov 1984) from 56 Santomeans who live in the capital or its surrounding (for a total of $46 \mathrm{~h}$ of recording) (Table 1). The focus is on Santomeans who identify as Forros. ${ }^{8}$

Table 1. Sample of Santomeans for data, by age, education level, and gender.

\begin{tabular}{cccccccc}
\hline \multirow{2}{*}{ Age } & \multicolumn{2}{c}{ Primary } & \multicolumn{2}{c}{ High School } & \multicolumn{2}{c}{ University } & \multirow{2}{*}{ TOTAL } \\
\cline { 2 - 6 } & Female & Male & Female & Male & Female & Male & \\
\hline $12-18$ & 1 & 0 & 3 & 4 & 0 & 0 & 8 \\
$20-29$ & 2 & 2 & 2 & 2 & 2 & 2 & 12 \\
$30-39$ & 2 & 2 & 2 & 2 & 2 & 2 & 12 \\
$40-49$ & 2 & 2 & 2 & 2 & 2 & 2 & 12 \\
$50+$ & 2 & 2 & 2 & 2 & 2 & 2 & 12 \\
TOTAL & 9 & 8 & 11 & 12 & 8 & 8 & 56 \\
\hline
\end{tabular}

The data collected is primarily natural speech and indicative of the speech that participants use in everyday interactions (Labov 1972). Interviews were carried out employing techniques from both sociolinguistic interviews (Labov 1984) and ethnographic interviews (Spradley 1979). The friend-of-a-friend technique (Milroy 1980) is extremely useful in São Tomé and Príncipe to find participants, as it allows for a "snowball" effect, which can build up one's set of community contact very quickly. This technique worked particularly well in São Tomé because the country is small, and most Santomeans know many people through their large and extended families. They say that "STP", the acronym for São Tomé and Príncipe also stands for Somos Todos Parentes 'we are all family'. Excerpts from these interviews are presented in this paper, and pseudonyms are used to maintain the confidentiality of the participants.

\section{From Societal Multilingualism to Societal Monolingualism}

According to Hagemeijer (2018), it is reasonable to assume that during colonial times, Santomeans belonging to the higher social class and slaves that had an everyday contact with the Portuguese were bilingual (in Portuguese and Forro, most probably, as Angolares were living on the margin of the society). In 1766, Pinheiro da Câmara wrote that everybody on São Tomé Island spoke Portuguese (e hé certo que todos sabem falar a portuguesa (Espírito Santo 1998, p. 59). But Hagemeijer (2018) questions this affirmation as it is unlikely that the number of native Portuguese speakers was high enough for the non-Portuguese speakers to acquire this language. The author rather agrees with Melo e Almada (1929, p. 184) who wrote that all Forros (i.e., the Santomeans living in and around São Tomé City, the ones forming the main ethnic group on the island and having a closer contact with Portuguese nationals)

8 Although there is a general tendency toward monolingualism in the country, it is important to mention that not all linguistic communities are at the same stage. For example, according to my observations, level of bilingualism among Angolares is still high, or at least, higher than among Forros in the capital. 
who did not have a close relationship with the colonizers did not know Portuguese (Hagemeijer 2018, p. 173). It is only later in the history of São Tomé Island that Portuguese became accessible and more widespread.

Starting in the middle of the nineteenth century, with the arrivals of foreign workers during the second phase of colonization, Portuguese became the dominant lingua franca of São Tomé Island: "Portuguese kept expanding, mostly as a L2 but with a growing number of bilinguals" (Hagemeijer 2018, p. 177). Consequently, it seems right to assume that the highest level of multilingualism on the islands was between mid-nineteenth to mid-twentieth century, with Portuguese as a L2.

In this light, we can ask the questions: Why did the Santomean society did not maintain its bilingualism (or multilingualism, as some Santomeans might have been able to speak Portuguese, Forro, and Angolar)? Why and how was Portuguese chosen as the language that would become the language of the vast majority of the population rather than creole, like it was the case in Cape Verde for example, where all Cape Verdeans speak krioulu as a L1 even if Portuguese is the official language of the country? Based on my fieldwork research and many discussions with Santomeans on the topic, I believe that the highly pejorative ideologies linked to creoles disfavored the use of these languages. In fact, at some point around the middle of the twentieth century, speaking a creole language started to be associated with being uncivilized, backward, and savage (Bouchard 2017). In Excerpt 1, Bibiana explains how the creole languages were perceived (by Portuguese and Santomeans) as "less valuable" as the Portuguese language.

Excerpt 1. Creole languages perceived as less valuable

Houve uma altura em que havia uma certa eeh... como que ia dizer, um certo preconceito relativamente a essas linguas porque a politica ass... assimiliacionista, colonial, levava-nos para... para este ponto eeh... considerávamos as nossas línguas como minoritárias no sentido em que não tinham o mesmo valor que as linguas oficiais ou do colono, e então as pessoas para terem alguma (?) a nível social, apontaram mais na lingua do colonizador, para terem uma ascensão social sobretudo.

'There was a time in which there was some kind of ... how to say that, some kind of prejudice regarding these languages because the colonial ass ... assimilationist politics would lead us to ... to this point ... we considered our languages to be in minority in the sense that they didn't have the same value as the official or colonial languages, so people to have some kind of (?) at the social level aimed toward the colonizer's language, to gain upward mobility, mainly.' (Bibiana, 54 years old)

Bibiane clearly expresses how the creole languages were depreciated in the Santomean society while the Portuguese language was rather linked to upward mobility. These beliefs may have contributed to the underestimate of the creole languages and the reduction of their use. Such ideologies were common in the history of colonial societies, where the language of the colonizers become the language of prestige (e.g., French in Haiti, English in Jamaica, and Dutch in Aruba, Bonaire, and Curação). Probably as a consequence of these ideologies, around 1960, Santomean parents started to forbid their children to speak Forro and encourage them to speak Portuguese instead, as explained by Elzo in Excerpt 2.

Excerpt 2. Forbidden to speak creole

Meu avô, hum... falava muito bem o dialeto mas sempre primou para que nós falássemos português, tanto é que ele mesmo naquela altura fazia questão que nós lêssemos muito, levava os jornais e não sei quê, que é pra nós lermos e quando nós falássemos mal uma palavra, ele corrigia logo [ok] sim, ele não queria que nós falássemos o dialeto [ok] não queria mesmo [han] sim, corrigia logo.

'My grandfather, hum ... he spoke Forro very well but he always made an effort for us to speak Portuguese, so much that at that time he made sure that we read a lot, he would bring 
journals home and all that so we would read them, and if we would say a word badly, he would correct it right away [ok] yes, he didn't want us to speak Forro [ok] he really didn't want [han], he would correct us right away.' (Elzo, 50 years old)

Speaking Portuguese, and speaking a good Portuguese, was essential for Santomeans of the higher social class (as for Elzo's family). However, the beliefs of prestige associated to the Portuguese language and speakers then spread to all social classes, especially around the capital. Social classes are not easy to grasp in Santomean society, and it did not feel appropriate to ask questions about socioeconomic status during my interviews. Ascription of social classes is based on different factors, such as level of education and occupation, but also racial group, family name, and neighborhood, among others. Level of education is probably the best indicator of social class. And interestingly, there is no direct correlation between one's level of education and the language(s) they speak. In other words, it is mistaken to assume that Santomeans with a lower level of education are creole speakers and those with a higher level of education are monolingual in Portuguese. In fact, some Santomeans with a high level of education are creole speakers, and some Santomeans with a low level of education are monolingual speakers of Portuguese (Table 2).

Table 2. Cross-tabulation between level of education and spoken languages (number of participants).

\begin{tabular}{cccc}
\hline & $\begin{array}{c}\text { Monolingual } \\
\text { (Portuguese L1) }\end{array}$ & $\begin{array}{c}\text { Portuguese L1 } \\
\text { (Some Creole L2) }\end{array}$ & $\begin{array}{c}\text { Bilingual } \\
\text { (Portuguese and Creole) }\end{array}$ \\
\hline primary school & 5 & 6 & 6 \\
high school & 3 & 14 & 6 \\
university & 4 & 10 & 2 \\
\hline Total & 12 & 30 & 14 \\
\hline
\end{tabular}

According to my informants, when parents and teachers started to forbid the use of creoles, these languages were considered to be ugly (feio), inferior (inferior), marginalized (marginalizado), and animal's language (lingua de bicho). ${ }^{9}$ Forro parents were worried that creole would hinder their children's acquisition of Portuguese and limit their social mobility. This certainly contributed to a rapid language shift, mainly in the capital and its surrounding, from Forro to a Santomean variety of Portuguese. São Tomé Island is small $\left(1001 \mathrm{~km}^{2}\right)$, so one can imagine how ideas, beliefs, news, languages, etc., can spread quickly from one community to another. Tomás gave me this metaphor (presented in Excerpt 3) to underline how the smallness of the island is an important element to take into consideration when considering the spread of the Portuguese language on São Tomé Island:

Excerpt 3. The spread of Portuguese on the island.

Eu posso the dizer pa seu estudo que o principal cada dessas particularidades é a insularidade e a pequenez. Sabe que quando, quando tens um líquido, um recipiente, tens um líquido por exemplo verde, tú botas pingos de vermelho, se o recipiente é grande, os pingos de vermelho não vão influenciar a mudança da cor, mas se o recipiente é pequeno, a influença é muito grande, a cor vai mudar, é isso mais ou menos, metaforicamente, é assim que a gente pode entendê-lo.

'I can tell you for your study that the main characteristics are insularity and smallness. You know when, when you have a liquid, a recipient, you have a green liquid for example, you put red drops, if the recipient is big, the red drops won't influence the change of color, but if the recipient is small, the influence is very big and the color will change, that's it, more or less, metaphorically, that's how we can understand this.' (Tomás, 50 years old)

9 All evaluative characteristics and comments included in the text come from my interviews with Santomean informants. 
In fact, the size of São Tomé and Príncipe is likely an important element in explaining the rapid growth of L1 speakers of Portuguese, especially compared to other former Portuguese colonies that are territorially vaster, such as Mozambique and Angola.

That being said, speaking Portuguese itself was not enough to "become someone" (ser alguém)—not speaking creole was also necessary. In fact, this element is key to understanding why Santomeans are moving from being a creole-speaking or bilingual society to a monolingual Portuguese-speaking society. According to a few informants, not speaking creole is, still today, important to many Santomeans. When comparing Santomeans to Cape Verdeans ${ }^{10}$, a Santomean friend who has been living in the European diaspora for many years once told me that some Santomeans "feel proud of saying 'I don't know how to speak the creole of São Tomé!"' (se sentem orgulhosos em dizer "Eu não sei falar o crioulo de São Tomé!"), contrary to Cape Verdeans who embrace their native language as an identity marker. This was reinforced by a number of informants on São Tomé Island, including Alberto who has studied abroad and spent time in Brazil and Cape Verde:

Excerpt 4. Feeling ashamed of speaking creole

Os Caboverdianos usam bastante mais o seu crioulo, que é... falam o tempo inteiro [ ... ] o pessoal passa falando crioulo em vez de falar português, e Santomense não, Santomeanse cá em São Tomé tem receio de falar Forro assim publicamente, nas escolas quase não se ouve, maior parte dos jovens nem falam Forro.

'Cape Verdeans use their creole more, which is ... they speak all the time [ ... ] they spend their time speaking creole instead of Portuguese, but Santomeans no, Santomeans here in São Tomé are ashamed of speaking Forro publicly, you don't really hear it in schools, most youths don't even speak Forro.' (Alberto, 32 years old)

I believe such ideologies to be key to understanding why multilingualism was, and is still not, promoted on São Tomé Island, as it stresses the impact of decades of pejorative ideologies toward the creole languages and indicates that they are still active in the mind of Santomeans. The negative beliefs associated to creole languages and speakers as well as the rejection of speaking creole to mark one's position in the society were combined with the belief that "creole spoils Portuguese" (o crioulo estraga o português) (Tomás, 50 years old). In fact, this was a common belief in many creole and non-creole societies, and it still holds today for many individuals.

In 1975, with the independence of São Tomé and Príncipe, Portuguese was chosen as the only official language of the country. Portuguese appeared as an instrument to unify all Santomeans under one nation, a Portuguese-speaking nation. I believe that an ideology and a culture of monoglot standardization underly the Santomean constitution. Silverstein (1996, p. 285) wrote that "a culture of monoglot standardization (or standard) can be demonstrated by showing the ways that this ideal underlies people's understanding of linguistic usage in their community, how it lies behind, or is presupposed by, the way people understand sociolinguistic behavior to be an enactment of a collective order." Santomeans have been transmitting ideas and beliefs regarding the "superiority" of the Portuguese languages and the "inferiority" of the creole languages for at least one century now, and many arguments have been constructed and transmitted to endow such claims of superiority and inferiority. This social stratification and hierarchization of the languages are being maintained through institutions and the everyday language use.

That being said, there is no official data on bilingualism in São Tomé and Príncipe. The census does not provide information regarding bilingualism and multilingualism. For example, no numbers indicate which language a speaker considers to be their L1(s). The question that was asked in the

10 São Tomé and Príncipe and Cape Verde are often compared, most probably because of the historical links between these two former Portuguese colonies. 
last census was Quais linguas que o(a) Sr(s) fala? 'What language(s) do you speak?' (INE 2012a, p. 24). But generally speaking, a higher number of older Santomeans are speakers of a creole language compared to younger Santomeans (INE 2012a, p. 78). Among my informants, the younger generations (people under fifty years old, more or less) speak Portuguese as a L1, and Forro as a L2 if they know it at all, contrary to the older generation (people over fifty years old) which speaks Forro as a L1 and Portuguese as a L2, or are balanced bilinguals. The variable spoken languages is based on the informants' self-assessment of language skills. See Table 3.

Table 3. Cross-tabulation between age and spoken languages (number of participants).

\begin{tabular}{cccc}
\hline & $\begin{array}{c}\text { Monolingual } \\
\text { (Portuguese L1) }\end{array}$ & $\begin{array}{c}\text { Portuguese L1 } \\
\text { (Some Creole L2) }\end{array}$ & $\begin{array}{c}\text { Bilingual } \\
\text { (Portuguese and Creole) }\end{array}$ \\
\hline $12-18$ & 4 & 3 & 1 \\
$20-29$ & 5 & 7 & 0 \\
$30-39$ & 2 & 7 & 3 \\
$40-49$ & 0 & 10 & 2 \\
$>50$ & 1 & 3 & 8 \\
\hline Total & 12 & 30 & 14 \\
\hline
\end{tabular}

It is difficult to give an age range for those generations because it varies a lot depending on the part of the island the speakers are from and their family background, but based on my interviews, Santomeans who are over fifty years old are the ones who acquired Forro as a L1. Also, note that there is more (balanced) bilingualism among older speakers. This shift between generations has parallels with Van Coetsem's (1988) three-generation model in the United States among immigrants: The first generation comes to the United States speaking their L1, the second generation starts out with the parents' L1 as their L1, and then acquire English (in school and elsewhere), and by the time they are adults English is their dominant language, and finally the third generation grows up with English at home as an L1.

However, the concept of L1 and L2 might not be entirely relevant to most Santomeans. Afonso (2008, p. 134) noted that A maioria dos são-tomenses teria dificuldade em responder com prontidão e segurança qual é a sua lingua materna 'Most Santomeans would have a hard time in telling with readiness and confidence what their mother tongue is'. In fact, I also noted during my interviews that some Santomeans would tell me that their mother tongue is creole, even if they do not speak that language. But I agree with Phillipson and Skutnabb-Kangas (2013) in considering "mother tongue" to be a socially-constructed concept. Even when it does not correspond to the linguists' definition of a mother tongue or a L1, this idea or perception is still true in the mind of the Santomeans who consider creole to be their mother tongue. As Phillipson and Skutnabb-Kangas (2013, p. 509) wrote, reporting Pattanayak (1992), mother tongue is "an identity signifier waiting to be explained." In the case of São Tomé and Príncipe, mother tongue refers to their cultural and historical heritage languages, i.e., the native creole languages of the islands.

Assessing the level of bilingualism on São Tomé Island (as it in many other places) and understanding the range of knowledge and speech competence of my participants in creole is definitely challenging. When I would ask them "Do you speak creole?", the most frequent (and puzzling) answers would be mais ou menos 'kind of' or um bocado 'a little'. (In Table 2, these answers are grouped under "some" creole L2.) On a few occasions, I questioned further what it meant to them to "kind of" speak creole, or to speak it "a little". The answer would usually refer to an incomplete knowledge of the language, and sometimes to a certain insecurity.

Excerpt 5. Speaking more or less creole.

Um pouco, quer dizer eeh, não todo a pessoa sabe, pequenas coisas (risos) pequenas coisas, exacto, porque depois eeh... as pessoas que viveram com os mais velhos [hum hum] aí sim se calhar podem 
falar mesmo (risos) ou então as pessoas que viveram na roça, ya, sim. Porque aqui na cidade fala-se muito pouco [hum hum] fala-se muito pouco, mas as coisas essenciais eu posso falar (risos).

'A little, I mean, eeh, the person doesn't know everything, small things (laughs) small things, exactly, because then eeh... people who grew up with elders [hum hum] then yes, they probably speak better (laughs) or people who lived in a plantation, yeah. Because here in the city it is not spoken much [hum hum] it is not spoken much, but the essential things I know how to say them (laughs).' (Catarina, 43 years old)

As noted in Excerpt 5, Catarina is self-conscious about her proficiency in creole and she lacks confidence. This linguistic insecurity was observed among many Santomeans. This certainly marks the language shift toward Portuguese and the tendency towards monolingualism in Portuguese. However, bilingualism in Portuguese and another foreign language would be perceived differently than bilingualism in Portuguese and creole. Many Santomeans from the middle and higher social classes take French lessons at the Alliance Française. And after the country established political relations with China in December 2017, a small school offering Mandarin classes opened. This suggests that there exist different ideologies regarding bilingual individuals, where bilingualism in Portuguese and a foreign (probably European) language is socially more valued than bilingualism in Portuguese and creole.

Interestingly, it is often when abroad that Santomeans learn Forro and start to give more value to the native creoles of their country. The following excerpt highlights this observation:

Excerpt 6 . The learning and valuing of creole when abroad

E então, 'tar lá fora faz nos aprender a valorizar o que é nosso, quem somos realmente, por exemplo, eu aprendi o crioulo forro lá fora [Ah é], estando lá fora, sim, comecei a dar maior importância ao crioulo lá fora [Que estranho...] é... [E... por quê?] Aquilo me identificava como Santomense.

'So, being abroad teaches us to give value to what is ours, to who we really are, for example, I learned Forro abroad. [Oh, really?] While being abroad, yes, I started to give more importance to Forro abroad. [Interesting ... ] Yeah ... [And, why so?] It marked me as Santomean.' (Sandra, 38 years old)

Sandra, as other Santomeans who have lived abroad, embrace Forro as the spoken embodiment of their Santomean identity. For these Santomeans, Forro is a unifying force, one that they use to set themselves apart from other Portuguese speakers when they are abroad. Most of my informants who have studied abroad (mainly Portugal) told me they have learned and started to use creole among the diaspora as a "secret code", for the locals and other Portuguese-speaking Africans 'not to understand what they say' (não perceberem o que estão a falar) (Otávio, 40 years old).

However, once back on São Tomé Island, most Santomeans who have learned Forro abroad do not necessarily use it more frequently in their everyday life. And like most Santomeans I have met, most place in the hands of the government the responsibility of maintaining Forro and providing the conditions that would allow Santomeans to learn and practice it. Here is an example that comes from my interview with Pedro:

Excerpt 7. The future of the creole languages in the hands of the government.

Eu não sei porque as pessoas deixaram... estão a deixar isso pra trás, mas está tendo um esforço, eu até dizia assim, se o governo por exemplo colocar disciplina na escola ou abrir uma escola especificamente pra isso, vou me matricular, porque quero aprender.

'I don't know why people leave ... are leaving this behind, but there is an effort, I would even say this, if the government implemented a course of Forro in school or if it'd open a school specifically for that, I'd register, because I want to learn.' (Pedro, 31 years old) 
But the question is: Is there a real desire from the policy makers and educators to implement the learning of Forro (and other creole languages) in schools? Does the government want to promote bilingual education, with both creole and Portuguese? Many Santomeans have told me that this is under discussion, already within the government's hands, but I have not seen or heard of any concrete plans to introduce the use of creoles at a national level. However, there is definitely an effort coming from a few Santomeans who have created Facebook pages and programs on television and radio, and from the community of linguists, who have written grammars (e.g., Maurer (1995) on Angolar, Maurer (2009) on Lung'ie), dictionaries, (e.g., Araújo and Hagemeijer (2013) for Forro-Portuguese, Maurer (1995) for Angolar-Portuguese, Araújo (2012) and Araújo et al. (forthcoming) for Lung'ie-Portuguese), and a proposition for a unified orthography for the native creoles of both islands, called the Alfabeto Unificado para a Escrita das Linguas Nativas de São Tomé and Principe (ALUSTP) ‘Unified Alphabet for the Writing of the Native Languages of São Tomé and Príncipe'. The effort of revitalization has been particularly important on Príncipe Island (cf. Agostinho 2014, 2016; Agostinho et al. 2016; and Lavres and Lavres 2016).

As for now, the future of these creoles is in the hands of Santomeans; the elders who can teach them, the parents who can transmit them to their children, the policy makers who can promote the introduction of creoles in the education system, the Santomeans who are abroad and value their native languages. But most of all, I believe that the future of the Santomean creoles is in the hands of the numerous Santomean children, teenagers, and young adults. They represent a high proportion of the population (60\% are under 25 years old (INE 2012b)). They have the power to transform ideologies and practices. They are the real key actors to change, although their role is underestimated, or even overlooked.

\section{Conclusions}

In this article, monolingualism on São Tomé Island is approached from a social and societal perspective. In this tiny island of the Gulf of Guinea, monolingualism is officially endorsed, with Portuguese as the only official language. This is, of course, a consequence of its colonization. As Edwards (2013, p. 7) wrote, "the languages of expansionist regimes often become intertwined with pragmatic advantage and cultural prestige at a local level, and those factors often long outlive the original dominating influence." The choice of Portuguese as an emblem of the nation was made on heavily ideological decisions. On the one hand, Portuguese was associated with national unity, modernity, European-ness, and the assumption that it would facilitate the creation of bonds with the international community (Espírito Santo 1983). The creole languages, on the other hand, were deprived of such qualities, and were rather associated with highly pejorative beliefs. This linguistic hierarchy on São Tomé Island has been maintained since the colonial times. It is not surprising that Portuguese was promoted at the expense of the local creole languages; European colonization to the "New" World favored the spread of global languages, and most of the largest European languages (e.g., French, English, Portuguese, Spanish) are widely spoken outside Europe (Romaine 2013). There is definitely a crucial link between such linguistic imperialism (i.e., the domination of certain languages internationally), and the endangerment of many other languages (cf. Phillipson and Skutnabb-Kangas 2013).

The community that the Santomeans working towards the independence of São Tomé and Príncipe "imagined", (cf. Anderson 1991) was a unified Portuguese-speaking nation. To my knowledge, the choice of Portuguese as the only official language of the country has not led to bitter controversy, as if most agreed this was the most "logical" decision to make. But of course, the transmission of a language is also socioculturally constructed. Monolingualism is not "an automatic or inevitable outcome" (Fishman 2013, p. 469); it is rather the result of social, political, and economic realities experiences through time. The language shift on São Tomé Island was most probably already advanced in 1975, which facilitated the acceptation of Portuguese as the only official language of the country. By making such a decision, the Santomeans authorities favored linguistic homogenization over diversification. 
Could bilingualism in Portuguese and one creole language be promoted at a societal level? Or could the language shift in São Tomé and Príncipe be reversed (as it was the case for Maori, Irish, and Basque, (cf. Fishman 2013), for example)? My answer is quite pessimistic. There are no real discussions about introducing creole in the school system in São Tomé and Príncipe, there is little to no intergenerational transmission (especially among Forros), the creole languages are not used in the educational system, media, government, and most workplaces (exception to this would be among fishermen, palaiês (ladies who sell at the market), people working in the fields (palm oil, cocoa, etc.)), it is becoming harder to find native speakers of a creole language or even native bilinguals (although this observation varies according to the creole language), the social status attributed to the creole languages is still very low, and Portuguese is still being promoted as the most prestigious language spoken on the islands. Bilingualism in creole and Portuguese is not perceived as an asset.

This article contributes to the study of growing monolingualism in Portuguese and the loss of the creole languages in São Tomé and Príncipe by filling some of the gaps in the literature-it offers a social perspective (rather than only historical) on the language shift underway on São Tomé Island, it examines discourse rather than the common societal causes of shift such as schooling and media, and it focuses on the impact of social practices and language ideologies in the everyday life of Santomeans rather than merely showing number from past censuses.

Funding: This research was funded by the SSHRC Doctoral Fellowship \#767-2012-1785 and the MacCracken Fellowship (New York University).

Conflicts of Interest: The author declares no conflict of interest.

\section{References}

Afonso, Beatriz de Castro. 2008. A Problemática do Bilinguismo e Ensino da Língua Portuguesa em São Tomé e Príncipe. Master's thesis, Universidade Nova de Lisboa, Lisbon, Portugal.

Afonso, Helena Lima. 2009. Interferências linguísticas: Um contributo para o ensino da língua portuguesa em São Tomé e Príncipe. Master's thesis, Universidade de Lisboa, Lisbon, Portugal.

Agostinho, Ana Lívia. 2014. Fonologia e método pedagógico do Lung'ie. Ph.D. dissertation, Universidade de São Paulo, São Paulo, Brazil.

Agostinho, Ana Lívia. 2016. Fonologia do Lung'ie. München: Lincom.

Agostinho, Ana Lívia, Manuele Bandeira, and Gabriel Antunes de Araujo. 2016. O Lung'ie na educação escolar de São Tomé, São Tomé e Príncipe. Trabalhos em Linguística Aplicada 55: 591-618. Available online: http://www.scielo.br/scielo.php?script=sci_arttext\&pid=S0103-18132016000300591\&lng=pt\&nrm= iso\&tlng=en (accessed on 2 May 2019).

Anderson, Benedict. 1991. Imagined Communities: Reflections on the Origin and Spread of Nationalism. London: Verso.

Araújo, Vanessa Pinheiro de. 2012. Um dicionário Principense-Português. Master's thesis, Universidade de São Paulo, São Paulo, Brazil.

Araújo, Gabriel, and Tjerk Hagemeijer. 2013. Dicionário Livre Santome-Português. São Paulo: Hedra Educação.

Araújo, Gabriel, Ana Agostinho, Vanessa Araújo, and Manuele Bandeira. forthcoming. Dicionário Lung'Ie-Português.

Bandeira, Manuele. 2017. Reconstrução fonológica e lexical do protocrioulo do Golfo da Guiné. Ph.D. dissertation, Universidade de São Paulo, São Paulo, Brazil.

Batibo, Herman. 2005. Language Decline and Death in Africa: Causes, Consequences and Challenges. Clevedon: Multilingual Matters.

Batibo, Herman. 2009. The inter-cultural dimension in the use of languages of wider communication by minority language speakers. Journal of Multicultural Discourses 4: 89-102. [CrossRef]

Baxter, Alan Norman. 2002. Semicreolization? The restructured Portuguese of the Tongas of São Tomé, a consequence of L1 acquisition in a special contact situation. Journal of Portuguese Linguistics 1: 7-39. [CrossRef]

Bouchard, Marie-Eve. 2017. Linguistic variation and change in the Portuguese of São Tomé. Ph.D. dissertation, New York University, New York, NY, USA. 
Bouchard, Marie-Eve. 2018. A distinctive use of $\mathrm{R}$ as a marker of Santomean identity. Journal of Belonging, Identity, Language, and Belonging. 2. Available online: http://bild-lida.ca/journal/volume_2_1_2018/bouchard/ (accessed on 10 May 2019).

Bouchard, Marie-Eve. 2019. Ongoing change in post-independence São Tomé: The use of rhotics as a marker of national identity among young speakers of Santomean Portuguese. Language Variation and Change 31: 21-42. [CrossRef]

Bouchard, Marie-Eve. forthcoming a. Language shift from Forro to Portuguese: Language ideologies and the symbolic power of Portuguese on São Tomé Island.

Bouchard, Marie-Eve. forthcoming b. Gente de cidade, gente de roça: A diferenciação de dois status sociais e variedades linguísticas da ilha de São Tomé. In O português na África Atlântica: Contatos no eixo afro-americano. Edited by Carlos Figueiredo, Marcia Oliveira and Tjerk Hagemeijer. São Paulo: Editora Humanitas.

Brandão, Silvia Figueiredo. 2011. Concordância nominal na variedade urbana do português falado em São Tomé. Ciências Humanas e Sociais em Revista 33: 31-42.

Butler, Yuko Goto. 2013. Bilingualism/multilingualism and second-language acquisition. In The Handbook of Bilingualism and Multilingualism, 2nd ed. Edited by Tej Bhatia and William Ritchie. Oxford: Blackwell Publishing, pp. 109-36.

D’Apresentação, Paula de Graça Bastos Varela. 2013. Influência do crioulo Forro na escrita do Português na crianças em idade escolar em São Tomé. Master's thesis, Universidade de Bragança, Bragança, Portugal.

Disney, Anthony. 2009. A History of Portugal and the Portuguese Empire: From Beginnings to 1807, Volume 2: The Portuguese Empire. New York: Cambridge University Press.

Edwards, John. 2013. Bilingualism and multilingualism: Some central concepts. In The Handbook of Bilingualism and Multilingualism, 2nd ed. Edited by Tej Bhatia and William Ritchie. Oxford: Blackwell Publishing, pp. 5-25.

Espírito Santo, Carlos. 1983. Situação linguística da língua portuguesa nas ilhas de São Tomé e Príncipe. In Actas do congresso sobre a situação actual da língua portuguesa no mundo. Lisbon: ICALP, pp. 253-63.

Espírito Santo, Carlos. 1998. O crioulo forro: Artigos, substantivos e adjectivos. Revista Camões 1: 54-59.

Eyzaguirre, Pablo. 1986. Small Farmers and Estates in São Tomé, West Africa. Ph.D. dissertation, Yale University, New Haven, CT, USA.

Ferguson, Charles. 1959. Diglossia. Word 15: 325-40. [CrossRef]

Ferraz, Luiz Ivens. 1974. A linguistic appraisal of Angolar. In Memoriam Antonio Jorge Dias. Lisbon: Instituto De Alta Cultura/Junta de Investigacões do Ultramar, vol. 2, pp. 177-86.

Ferraz, Luiz Ivens. 1979. The Creole of São Tomé. Johannesburg: Witwatersrand University Press.

Fishman, Joshua. 2013. Language maintenance, language shift, and reversing language shift. In The Handbook of Bilingualism and Multilingualism, 2nd ed. Edited by Tej Bhatia and William Ritchie. Oxford: Blackwell Publishing, pp. 466-94.

Garfield, Robert. 1992. A History of São Tomé Islands, 1470-1655: The Key to Guinea. San Francisco: Mellen Research University Press.

Gonçalves, Rita. 2010. Propriedades de subcategorização verbal no português de São Tomé. Master's thesis, Universidade de Lisboa, Lisbon, Portugal.

Gonçalves, Rita. 2016. Construções ditransitivas no Português de São Tomé. Ph.D. dissertation, Universidade de Lisboa, Lisbon, Portugal.

Hagemeijer, Tjerk. 1999. As ilhas de Babel: A crioulização no Golfo da Guiné. Revista Camões 6: 74-88.

Hagemeijer, Tjerk. 2000. Serial verb constructions in São-Tomense. Master's thesis, Universidade de Lisboa, Lisbon, Portugal.

Hagemeijer, Tjerk. 2009a. As línguas de São Tomé e Príncipe. Revista de crioulos de base lexical portuguesa e espanhola 1: $1-27$.

Hagemeijer, Tjerk. 2009b. Initial vowel agglutination in the Gulf of Guinea creoles. In Complex Processes in New Languages. Edited by Enoch Aboh and Norval Smith. Amsterdam and Philadelphia: John Benjamins, pp. 29-50.

Hagemeijer, Tjerk. 2009c. Aspects of a discontinuous negation in Santome. In Negation Patterns in West African Languages and Beyond. Edited by Norbert Cyffer, Erwin Ebermann and Georg Ziegelmeyer. Amsterdam and Philadelphia: John Benjamins, pp. 139-65. 
Hagemeijer, Tjerk. 2018. From creoles to Portuguese: Language shift in São Tomé and Príncipe. In The Portuguese Language Continuum in Africa and Brazil. Edited by Laura Álvarez López, Perpétua Gonçalves and Juanito Ornelas de Avela. Amsterdam and Philadelphia: John Benjamins, pp. 169-84.

Hagemeijer, Tjerk. forthcoming. São Tomé e Príncipe: Labirinto e laboratório de línguas. In Arquipélagos crioulos: Cabo Verde e São Tomé e Príncipe numa perspectiva comparada. Organized by Gerhard Seibart. Lisbon: Vega.

Hamers, Josiane, and Michel Blanc. 2000. Bilinguality and Bilingualism, 2nd ed. Cambridge: Cambridge University Press. Heller, Monica. 2007. Bilingualism: A Social Approach. New York: Palgrave Macmillan.

Henriques, Isabel de Castro. 2000. São Tomé e Príncipe: A invenção de uma sociedade. Lisbon: Vega.

Hobsbawm, Eric. 1990. Nations and Nationalism since 1780: Programme, Myth, Reality. Cambridge: Cambridge University Press.

Hodges, Tony, and Malyn Newitt. 1988. São Tomé and Príncipe. From Plantation Colony to Microstate. Boulder and London: Westview Press.

Instituto Nacional de Estatística (INE). 2012a. Características educacionais da população. IV Recenseamento geral da população e habitação. Available online: http://www.ine.st/Documentacao/Recenseamentos/ 2012/TemasRGPH2012/11CARACTERISTICAS\%20EDUCACIONAIS\%20\%20DA\%20POPULACAO\% 20Recenseamento\%202012.pdf (accessed on 28 April 2019).

Instituto Nacional de Estatística (INE). 2012b. Características económicas da população. IV Recenseamento geral da população e habitação. Available online: http://www.ine.st/Documentacao/Recenseamentos/ 2012/TemasRGPH2012/5\%20ACTIVIDADEECONOMICA\%20Recenseamento\%202012.pdf (accessed on 28 April 2019).

Irvine, Judith. 1989. When talk isn't cheap: Language and Political Economy. American Ethnologist 16: 248-67. [CrossRef]

Jaffe, Alexandra. 2007. Minority language movements. In Bilingualism: A Social Approach. Edited by Monica Heller. New York: Palgrave Macmillan, pp. 50-70.

Labov, William. 1972. Sociolinguistic Patterns. Philadelphia: University of Pennsylvania Press.

Labov, William. 1984. Field methods of the project on linguistic change and variation. In Language in Use: Readings in Sociolinguistics. Edited by John Baugh and Joel Sherzer. Englewood Cliffs: Prentice-Hall, pp. 28-53.

Lavres, Nicolau, and Maria Lavres. 2016. Vika xina lung'Ie—Vem aprender lung'Ie. São Tomé: Lexonics Co.

Lorenzino, Gerardo. 1996. Uma avaliação sociolinguística sobre São Tomé e Príncipe. In Actas do Congresso Internacional sobre o Português. Organized by Inês Duarte and Isabel Leiria. Lisbon: APL e Edições Colibri, pp. 435-49.

Lorenzino, Gerardo. 1997. Synchronically speaking: Angolar Afro-Portuguese Creole "fara". Paper presented at Conference of the Society for Pidgin and Creole Linguistics, Chicago, IL, USA, January 3-4.

Lorenzino, Gerardo. 1998. The Angolar Creole Portuguese of São Tomé: Its Grammar and Sociolinguistic History. Ph.D. dissertation, City University of New York, New York, NY, USA.

Maurer, Philippe. 1992. L'apport lexical bantou en angolar. Afrikanische Arbeitspapiere 29: 163-74.

Maurer, Philippe. 1995. L'angolar: Un créole afro-portugais parlé à São Tomé. Hamburg: Helmut Buske Verlag.

Maurer, Philippe. 2009. Principense (Lung'Ie): Grammar, texts, and vocabulary of the Afro-Portuguese Creole of the island of Príncipe, Gulf of Guinea. London: Battlebridge.

Melo e Almada, Vicente Pinheiro. 1929. As ilhas de S. Thomé e Principe: Notas de uma administração colonial. Boletim Geral das Colónias 5: 179-87.

Milroy, Lesley. 1980. Language and Social Networks. New York: Blackwell.

Pattanayak, Debi Prasanna. 1992. Mother-Tongue Awareness. Cambridge: Cambridge University.

Phillipson, Robert, and Tove Skutnabb-Kangas. 2013. Linguistic imperialism and endangered languages. In The Handbook of Bilingualism and Multilingualism, 2nd ed. Edited by Tej Bhatia and William Ritchie. Oxford: Blackwell Publishing, pp. 495-16.

Romaine, Suzanne. 2013. The bilingual and multilingual community. In The Handbook of Bilingualism and Multilingualism, 2nd ed. Edited by Tej Bhatia and William Ritchie. Oxford: Blackwell Publishing, pp. 446-65.

Schang, Emmanuel. 2000. L'émergence des créoles portugais du golfe de Guiné. Ph.D. dissertation, Université Nancy 2, Nancy, France.

Seibert, Gerhard. 2006. Comrades, Clients and Cousins: Colonialism, Socialism and Democratization in São Tomé and Príncipe. Leiden: Brill. 
Silverstein, Michael. 1996. Monoglot "Standard" in America: Standardization and Metaphors of Linguistic Hegemony. In The Matrix of Language: Contemporary Linguistic Anthropology. Edited by Donald Brenneis and Ronald Macaulay. Boulder: Westview Press, pp. 284-306.

Spradley, James. 1979. The Ethnographic Interview. New York: Holt, Rinehart, and Winston.

Van Coetsem, Frans. 1988. Loan Phonology and the Two Transfer Types in Language Contact. Dordrecht: Foris.

Woolard, Kathryn. 1998. Introduction. Language ideology as a field of inquiry. In Language Ideologies: Practice and Theory. Edited by Bambi Schieffelin, Kathryn Woolard and Paul Kroskrity. Oxford: Oxford University Press, pp. 3-41.

Yakpo, Kofi. 2009. A Grammar of Pichi. Berlin and Accra: Isimu Media.

(C) 2019 by the author. Licensee MDPI, Basel, Switzerland. This article is an open access article distributed under the terms and conditions of the Creative Commons Attribution (CC BY) license (http://creativecommons.org/licenses/by/4.0/). 